\title{
E-Commerce Impact on the Shifting of Labor Demand in Indonesia 2015 - 2017
}

\author{
Arih Thoyyibatul Izdihar \\ STIS Polytechnic of Statistic \\ Jakarta, Indonesia \\ arihizdihar@gmail.com
}

\begin{abstract}
Electronic commerce is an excellent capital to support the Indonesian economy. However, e-commerce can shift the demand for labor through the reduction of conventional or retail employment and increase the demand for labor in the fields of Information, Communication, Technology, and knowledge (ICTD) which has the potential to increase unemployment. However, there has been no empirical research that discussed the impact of e-commerce on the shifting demand for labor in Indonesia. The purpose of this research is to find out the description and the factors that influence the demand for ICTD and conventional labor in Indonesia year 2015 - 2017. The statistical method used is panel data regression. This study proves that shifts in labor demand have occurred in Indonesia. E-commerce has a positive and significant effect on the demand for ICTD labor and negative and significant effect on the demand for conventional labor. Based on this research, the government needs to prepare public access facilities to be able to take advantage of e-commerce.
\end{abstract}

Keywords-Shifting of labor demand, e-commerce, and panel data regression

\section{INTRODUCTION}

As human life develops, there are new technologies growth in Indonesia. The latest technology penetration in Indonesia is often called "Industry 4.0", which is the fourth stage of the first industrial revolution that took place in the United Kingdom [21]. According to President Joko Widodo [19], the industry 4.0 has encouraged technological innovations that have disrupted or given fundamental changes to people's lives. The Minister of Industry, Airlangga Hartarto, stated that one form of industry 4.0 in Indonesia is electronic commerce (e-commerce) [15]. According to the World Trade Organization (WTO) (1998), e-commerce can be interpreted as the use of the internet to conduct business transaction activities both nationally and internationally [30]. E-commerce has become very popular in the era of globalization due to the widespread use of the internet.

Based on data from the World Bank [28], the percentage of internet users from the Indonesian population shows a trend that has increased rapidly from 1994 to 2017 along with the increasing population each year [30]. According to Managing Director of Google Indonesia, in Google's research [14], "Indonesia is a country that its internet user population will grow very rapidly in the next 10 years". In fact, according to the deputy governor of Bank Indonesia [2], e-commerce revenue growth is considered very important and has the potential to make a major contribution to the Indonesian economy. Supported by Ham \& Atkinson
[13], Suyanto [26], Schneider [20], Fraumeni [10], and Subramani [25].

In this regard, Economic Comission for Latin America and the Caribbean (ECLAC) [9] and Biagi \& Falck [5] state that the creation of technology-based employment occurs due to the inclusion of technological advances in the form of e-commerce. However, Terzi says that beside ecommerce is able to create jobs, it is also able to cause job losses [27]. New jobs will be generated in the technology, information and communication sectors, while job losses will occur in the retail sector, post office, and travel agency funds. However, this might be different for each country. This was supported by Cardullo who said that in the short term, the introduction of new technology would reduce jobs because productivity increased but the market did not increase, so only a small number of workers were able to meet market demand [18]. Most jobs which are reduced explained by Americo \& Veronico are a part of retail sector [3].

Based on previous statements, it is suspected that there is an influence of e-commerce on the shifting of labor demand in Indonesia. However, as far as the author's knowledge, there is no research available in Indonesia that discusses the influence of e-commerce on shifting labor demand empirically or using data and statistics. Therefore, research is needed to discuss the influence of e-commerce on the shift of labor demand empirically. So, the purpose of this study, are:

1) Understanding the description of ICTD and conventional labor demand, e-commerce, and the variables that affect other labor demand in Indonesia from 2015 to 2017.

2) Analyzing the influence of e-commerce and other variables on the demand for ICTD and conventional labor in Indonesia in 2015-2017.

Based on previous studies, generally the independent variables used are the number of sellers and buyers of goods and services online (e-commerce users), education (mean years schooling), wages (mean wage of ICTD worker), and road length as accessibility infrastructure. In this study, the dependent variables used are two, namely the demand for labor from conventional workers and ICTD workers.

Besides the selection of variables, the difference of previous related studies and this study is there are no similar studies that have focused on Indonesia, the country with a very rapid digital market development. This research is very 
necessary because it can detect the influence of e-commerce on the shift in demand for conventional labor to the demand for ICTD workforce in Indonesia.

\section{DATA AND Methodology}

The scope of this research is all provinces (34 provinces) in Indonesia with the 2015 to 2017 research period due to data limitations. The data used are sourced from the SAKERNAS and SUSENAS survey micro data estimates, some of which come from BPS Publication data. The analytical method used is descriptive analysis using graphs and inferential analysis using panel data regression. The following is a panel data regression model with research variables in general.

Model I:

$\operatorname{LNICTD}_{i t}=\alpha+\beta_{1} L N E C O M_{i t}+\beta_{2} L_{N M Y S_{i t}}+$

$\beta_{3} L N W A G E_{i t}+\beta_{4} L N R O A D L E N G T H_{i t}+u_{i t}$

Model II:

$L N C O N V E N_{i t}=\alpha+\beta_{1} L N E C O M_{i t}+\beta_{2} L_{N M Y S_{i t}}+$

$\beta_{3} L N W A G E_{i t}+\beta_{4} L N R O A D L E N G T H_{i t}+u_{i t}$

Where,

$\begin{array}{ll}\alpha & : \text { intercept } \\ \beta_{1}, \beta_{2}, \ldots, \beta_{4} & : \begin{array}{l}\text { slope coefficient for each independent } \\ \text { variable }\end{array}\end{array}$

LNICTD $_{i t} \quad$ : the natural logarithm of the number of ICTD-based workers for all workers in the $\mathrm{i}$-th province and $\mathrm{t}$-th year

$L_{N C O N V E N}$ it : the natural logarithm of the number of conventional-based workers for all workers in the i-th province and $\mathrm{t}$-th year

$L N M Y S_{i t} \quad$ : the natural logarithm of mean years schooling of workforce in the $\mathrm{i}$-th province and t-th year

LNECOM $_{i t}$ : the natural logarithm of number of ecommerce users in the $\mathrm{i}$-th province and $\mathrm{t}$ th year

$L N W A G E_{i t} \quad$ : the natural logarithm of mean wage of ICTD workers in the $\mathrm{i}$-th province and $\mathrm{t}$-th year

LNROADLENGTH $H_{i t}$ : the natural logarithm of sum of length of road in the $\mathrm{i}$-th province and $\mathrm{t}$-th year

$u_{i t} \quad:$ error component in the $\mathrm{i}$-th province and tth year

i : 34 province in Indonesia

t $\quad: 2015,2016$, and 2017 follows:

The operational definitions of these variables are as

\section{1) Shifting of labor demand}

The demand for labor is the number of the workforce with employment status [6]. ICTD-based workers are workers who in their jobs involve expertise in technology, information, communication, and expertise in certain knowledge [5,18]. Expertise in technology, for example data scientist, while expertise in certain knowledge, for example business intelligence. The demand for ICTD workforce is the number of workers based KBJI code 2 and 3. Conventional based workers are workers who in their jobs can slowly be replaced with machines and digital [16]. Examples are shopkeepers, manual laborers, and so on. The demand for conventional labor is the number of workers based KBJI code 5 and 9 . In this study, the variables to be included in the model as the dependent variable are worth the natural logarithms of each number of requests for ICTD and conventional labor.

\section{2) Mean years schooling of workforce}

As technology develops, an increasingly skilled labor is needed to operate the technology. Thus, the demand for technology skilled labor increases, and the demand for technology unskilled labor decreases [6].

Education strongly reflects the quality of the workforce itself. This is in accordance with the labor demand theory which explains that the level of quality of labor is in education and skills. The quality of the population related to education can be measured using the Human Development Index (HDI) or the mean years schooling (MYS), but it is more often used the mean years schooling. Therefore, because in this study the intended population is the labor force, the quality of the workforce can be measured using MYS. The MYS workforce is formulated as follows.

$$
\begin{gathered}
\text { MYS }=\frac{1}{A K} \sum_{i=1}^{A K}(\text { length of school of } i- \\
\text { thworkforce })
\end{gathered}
$$

where length of school defined by:

- Never go to school $=0$

- During education in elementary school up to bachelor degree $=$ conversion of last diploma + last class -1

- During education of master or doctor $=$ conversion of the last diploma +1

- Not going to school anymore = conversion of the last diploma

3) Number of e-commerce users

E-commerce is a means for producers or traders to sell their products online or through certain media using the internet. E-commerce in this case prioritizes e-commerce with the business to consumer model. In other words, specifically for transactions that occur between producers and consumers. One of the variables that can record the existence of e-commerce activities in Indonesia is the number of e-commerce users or the number of residents who use the internet to sell or buy goods online.

\section{4) ICTD mean wage}

In this study, the wage is the mean wage or salary of workers in all regencies/cities in one province. So that the mean wage of ICTD workers is the mean wage received by ICTD workers in all regencies/cities in each province in Indonesia. The mean wage can represent the level of wages in an industry, so it is good to be used in this study [31]. The optimal amount of labor used can be influenced by the wage rate. If the wage rate decreases, the labor force requested will increase. Likewise, conversely the higher the wage level, the requested labor will be lower [6]. 


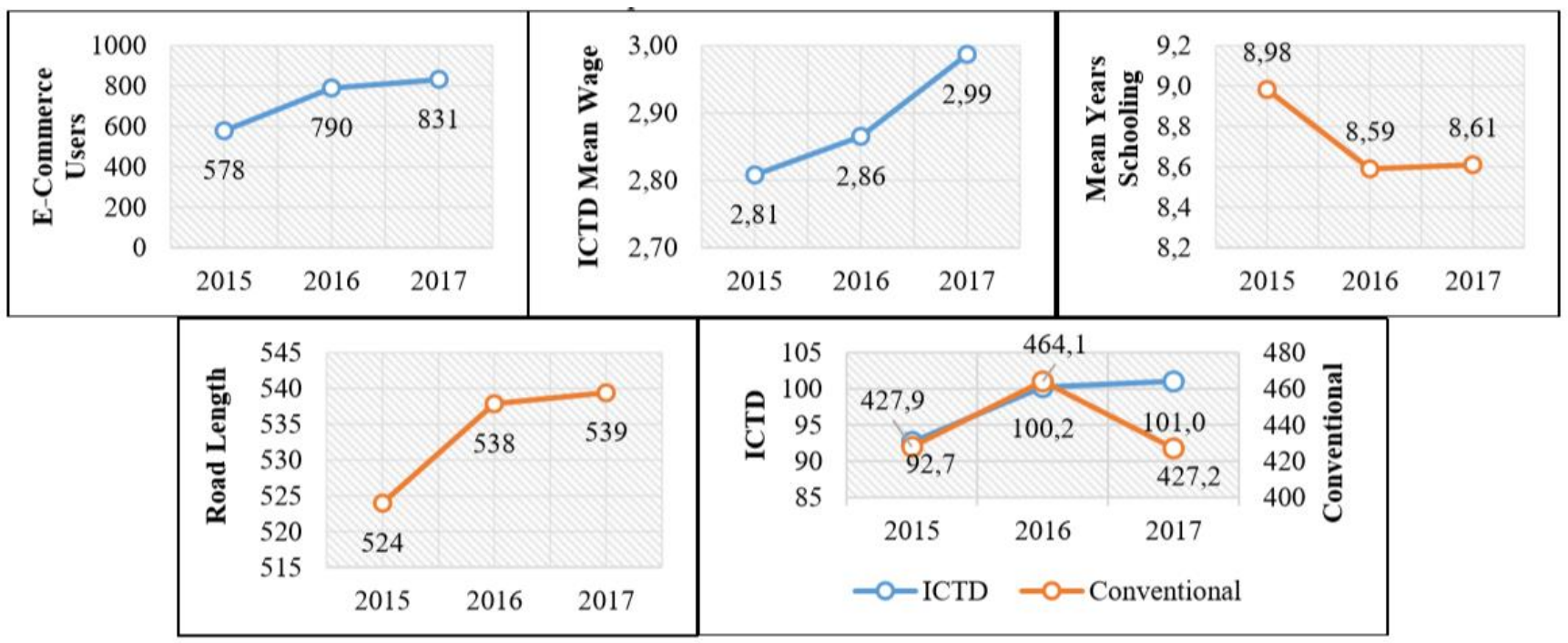

Source: BPS, processed

Fig. 1. E-commerce users (tens of thousands people), ICTD mean wage (million rupiahs), MYS (years), road length (thousand km), and the demand of ICTD and conventional workers 2015-2017

\section{5) Length of road}

Regional accessibility in this study is the quantity of facilities and infrastructure in an area that reflects the quality of the area concerned, such as the length of the road, the number of schools, the number of hospitals, and others. In this study, the accessibility in question is the length of the road in one province. The more attractive a region means to have good transport infrastructure and accessibility, the more employment will be absorbed. Conversely, the less infrastructure and accessibility of an area, the smaller the absorption of its workforce. This is because of the ease of travel [8].

\section{RESULT AND DISCUSSION}

Based on the graph in figure 1, e-commerce users, the mean wage of ICTD workers, and length of road show a same direction pattern each year, which is also in line with the development of ICTD labor demand, but not too visible in the development of demand for conventional labor. Whereas, the workforce's MYS has the same pattern of conventional labor development. This pattern of development is precisely the opposite of the demand for conventional labor, but it is not in line with the demand for ICTD labor.

The development of e-commerce in accordance with Borjas's theory [6] and research from Terzi [27], Biagi \& Falck [5], and Cardullo [7] states e-commerce is able to increase the demand for labor with ICTD capabilities.

Besides e-commerce, Borjas [6] explains that the quality of the workforce (MYS), greatly influencing the demand for labor, because companies will tend to recruit high-quality workforce because it tends to produce high productivity. The development in the same direction as the mean wage and the demand for ICTD contradicts Borjas's theory [6], but supported by Biagi \& Falck [5] in his research stating wages have a direct effect on labor demand, because the higher the ICTD wages, the greater the motivation workforce to get jobs in the ICTD sector that have high wages. For the road length, Moller \& Zierer [17] explained that the longer the road in an area, the greater the accessibility of the community in the area. So that, firms can absorb new workers more.
Besides analyzing using graphics, this study also discusses inferential analysis using panel data regression. The panel data regression model that has been selected is used to explain the relationship and the effect of independent variables on the dependent variable. Based on the previous test results, the chosen model is the Fixed Effect Model (FEM) and the estimated method of Feasible Generalized Least Square (FGLS) with Seemingly Unrelated Regression (SUR). The model estimation in the form of the equation produced is:

Model I:

$\begin{aligned} \text { LNICTD ` it }= & (4,64+\mu \hat{i} *)+0,12 \text { LNECOMit* }- \\ & 0,32 \text { LNMYSit }+0,04 \text { WAGEit }+ \\ & 0,64 \text { LNROADLENGTHit } *\end{aligned}$

Model II:

LNCONVEN ^ $i t=(20,81+\hat{\imath} i *)-0,14$ LNECOMit* 2,08 LNMYSit $*$ + 0,13LNWAGEit + $0,05 R O A D L E N G T H i t$

*significant in $5 \%$

TABLE I. INDIVIDUAL FIXED EFFECT

\begin{tabular}{|l|c|c|l|c|c|}
\hline Province & $\begin{array}{c}\text { Model } \\
\text { Effect } \\
\text { I }\end{array}$ & $\begin{array}{l}\text { Model } \\
\text { Effect } \\
\text { II }\end{array}$ & Province & $\begin{array}{c}\text { Model } \\
\text { Effect } \\
\text { I }\end{array}$ & $\begin{array}{c}\text { Model } \\
\text { Effect } \\
\text { II }\end{array}$ \\
\hline Aceh & 0.015 & 0.303 & $\begin{array}{l}\text { Nusa } \\
\text { Tenggara } \\
\text { Barat }\end{array}$ & 0.315 & 0.118 \\
\hline $\begin{array}{l}\text { Sumatera } \\
\text { Utara }\end{array}$ & 0.264 & 1.509 & $\begin{array}{l}\text { Nusa } \\
\text { Tenggara } \\
\text { Timur }\end{array}$ & -0.165 & -1.086 \\
\hline $\begin{array}{l}\text { Sumatera } \\
\text { Barat }\end{array}$ & -0.123 & 0.376 & $\begin{array}{l}\text { Kalimantan } \\
\text { Barat }\end{array}$ & -0.344 & -0.249 \\
\hline Riau & -0.146 & 0.702 & $\begin{array}{l}\text { Kalimantan } \\
\text { Tengah }\end{array}$ & -0.543 & -0.569 \\
\hline Jambi & -0.249 & -0.147 & $\begin{array}{l}\text { Kalimantan } \\
\text { Selatan }\end{array}$ & -0.029 & 0.074 \\
\hline $\begin{array}{l}\text { Sumatera } \\
\text { Selatan }\end{array}$ & 0.252 & 0.723 & $\begin{array}{l}\text { Kalimantan } \\
\text { Timur }\end{array}$ & 0.052 & 0.330 \\
\hline Bengkulu & -0.409 & -0.849 & $\begin{array}{l}\text { Kalimantan } \\
\text { Utara }\end{array}$ & -0.812 & -1.812 \\
\hline
\end{tabular}




\begin{tabular}{|l|c|c|l|c|c|}
\hline Province & $\begin{array}{c}\text { Model } \\
\text { Effect } \\
\text { I }\end{array}$ & $\begin{array}{c}\text { Model } \\
\text { Effect } \\
\text { II }\end{array}$ & Province & $\begin{array}{c}\text { Model } \\
\text { Effect } \\
\text { I }\end{array}$ & $\begin{array}{c}\text { Model } \\
\text { Effect } \\
\text { II }\end{array}$ \\
\hline Lampung & 0.043 & 0.616 & $\begin{array}{l}\text { Sulawesi } \\
\text { Utara }\end{array}$ & -0.317 & -0.309 \\
\hline $\begin{array}{l}\text { Kepulauan } \\
\text { Bangka } \\
\text { Belitung }\end{array}$ & -0.588 & -0.991 & $\begin{array}{l}\text { Sulawesi } \\
\text { Tengah }\end{array}$ & -0.422 & -0.652 \\
\hline $\begin{array}{l}\text { Kepulauan } \\
\text { Riau }\end{array}$ & 0.247 & -0.237 & $\begin{array}{l}\text { Sulawesi } \\
\text { Selatan }\end{array}$ & 0.050 & 0.601 \\
\hline $\begin{array}{l}\text { DKI } \\
\text { Jakarta }\end{array}$ & 1.399 & 2.269 & $\begin{array}{l}\text { Sulawesi } \\
\text { Tenggara }\end{array}$ & -0.252 & -0.745 \\
\hline Jawa Barat & 1.583 & 3.117 & Gorontalo & -0.541 & -1.614 \\
\hline $\begin{array}{l}\text { Jawa } \\
\text { Tengah }\end{array}$ & 1.024 & 2.395 & $\begin{array}{l}\text { Sulawesi } \\
\text { Barat }\end{array}$ & -0.693 & -1.983 \\
\hline DIY & 0.827 & 0.626 & Maluku & -0.376 & -1.416 \\
\hline Jawa Timur & 1.043 & 2.705 & $\begin{array}{l}\text { Maluku } \\
\text { Utara }\end{array}$ & -0.698 & -1.906 \\
\hline Banten & 1.338 & 1.675 & Papua Barat & -0.904 & -1.879 \\
\hline Bali & 0.363 & 0.619 & Papua & -1.202 & -2.312 \\
\hline
\end{tabular}

Because the chosen model is the FEM model, there are fixed cross-section or individual effects in this model which are provinces. After comparing the effects of individu, in both models, West Java is the biggest individual effect, and Papua is the lowest. This means that on average, if all provinces have the same number of e-commerce users, the same workforce MYS, the same mean wage of ICTD workers, and the same length of road, then the province with the highest number of ICTD and conventional labor demand changes in Java West, while the lowest number occur in Papua.

In model I, the effect of the number of e-commerce users on the value of shifting labor demand is positive, meaning that the more e-commerce users, the more the number of ICTD worker demands increase. This positive influence is in accordance with the research by Terzi [27], Biagi \& Falck [5], and Americo \& Veronico [3] who say that e-commerce can create new jobs so as to be able to increase the number of workers especially in the ICTD sector. As more ecommerce activities as part of technology, more workforce is needed to operate technology related to e-commerce. So, needed skilled workers in the field of technology and information. In addition, e-commerce is not only about technology and information, but also has a strong relationship with communication networks and business knowledge that require communication and knowledge experts [18].

In model II, the influence of the number of e-commerce users on the value of the shift in labor is negative, meaning that the more e-commerce users, the less the number of requests for conventional labor. This negative influence is in accordance with the research by Americo \& Veronico which says that e-commerce can automate a portion of conventional work in the retail sector [3]. As more e-commerce activities become part of technology, more technology is needed related to e-commerce. This technology will automate part of the work in the retail sector that is not needed. This causes a reduction in the need for conventional labor. So, e-commerce is able to reduce the demand for conventional labor.
Both models show different direction of influence from e-commerce on each independent variable. Model I shows that e-commerce is able to increase the demand for ICTD workers, while model II shows that e-commerce is able to reduce the demand for conventional labor. This difference in direction of influence shows that there is a shift in the demand for conventional labor to ICTD labor in Indonesia.

Based on the estimation results, in model I the value of the e-commerce user variable slope or coefficient is 0.12 , and in model II is -0.14 . This means that on average when ecommerce users increase by one percent, it will cause the number of ICTD labor demand to increase by 0.12 percent and the number of conventional labor demand decreases by

0.14 percent. The influence of e-commerce on increasing demand for ICTD labor is 0.02 percent smaller than the effect on decreasing demand for conventional labor. This shows that e-commerce has a greater effect when reducing the demand for conventional labor rather than increasing the demand for ICTD labor.

Beside the e-commerce influence, at the same time, model II also shows the negative influence of MYS on the demand for conventional and significant labor. This shows that the smaller the mean years schooling, the greater the demand for conventional labor. These negative effects are discussed by Aerden et al, where as time goes by, labor competition is getting tougher because of the increasing population and growing technology [1]. With the development of technology, labor is needed with adequate education so as to realize good quality education. A good quality workforce that will always survive in the labor market. Therefore, the MYS workforce can reduce the demand for conventional labor, because conventional labor is dominated by people with less education. Based on the estimation results which is significant, in model II is -2.08 . This means that on average when the mean years schooling workforce increases by one percent, it will cause the number of conventional labor demand decreases by 2.08 percent.

For the ICTD mean wage, in model II, the effect of the mean wage of ICTD workers is negative, meaning that the higher the mean wage of ICTD workers in a province, the lower the number of ICTD labor demand. This negative and significant influence is in accordance with the research by Biagi \& Falck in his research stating that wages have an effect on the demand for labor, because the higher the wage of ICTD, the greater the motivation of workers to get jobs in the field of ICTD that have high wages [5]. With the increasing demand for ICTD labor, jobs in conventional fields fail to compete and will reduce the demand for labor. Based on the estimation results in model II is -0.13 . This means that on average when the mean wage for ICTD increases by one percent, it will cause the number of conventional labor demand decreases by 0.13 percent.

For the road length, models I shows that the effect of the length of the road on the value of shifting labor demand is positive, meaning that the length of the road increases in a province, the higher the demand for ICTD and conventional labor. This positive influence is in accordance with the research by Terzi [27] and Biagi and Falck [5] who say that the accessibility can create access to the community so that it can increase the opportunities for community access. Opportunities for greater community access can encourage 
ease of obtaining employment opportunities, thereby increasing employment [17]. Based on the estimation results which is significant, in model I the slope value or coefficient of road length variable is 0.64 . This means that on average when the length of the road increases by one percent, it will cause the number of ICTD labor demand to increase by 0.64 percent.

\section{CONCLUSION}

Based on the analysis, there are several things that can be taken. Based on the picture of shifting labor demand and other variables, nationally in the $2015-2017$ period, it is clear that there is an increase in the demand for ICTD labor, but there is no clear effect of the decline in demand for conventional labor in line with the increased demand for ICTD labor.

Complementing this, it was concluded that the shift in labor demand actually took place in Indonesia and was influenced by factors such as e-commerce users, the mean wage of ICTD workers, the mean years schooling of the labor force, and road length.

Based on these conclusions, the suggestions put forward by the author both towards future research, as well as on government policies are:

1) Government should prepare the workforce to compete in the labor market especially in the demand for ICTDbased labor, support the development of e-commerce use and development of infrastructure (roads) especially in regions which are still lack of accessibility.

2) For further research, we can try to use the spatial panel regression method to overcome if there is a spatial dependence detected on the variables used, and use ecommerce transaction variables or use a percentage of ecommerce users to get a better estimate of the population in longer period.

\section{REFERENCES}

[1] Aerden, K. Van, et al. (2015). The Relationship between Employment Quality and Work-Related Well-Being in the European Labor Force.

Elsevier, Journal of Vocational Behavior, Vol.86, pp. 66-76

[2] Alaydrus, H. (2018). Increasing $190 \%$ BI said that E-commerce can be a hope. Finansial Bisnis. Accessed at $10^{\text {th }}$ September 2018 via http://finansial.bisnis.com/read/20180703/9/812271/tumbuh-190-bibilang-e-commerce-bisa-jadi-harapan. (in Indonesian)

[3] Americo, A dan A Veronico. (2018). The Effect of E-Commerce on Employment in Retail Sector. Università degli Studi

[4] Baltagi, B. H. (2005). Econometric Analysis of Panel Data Third Edition. Inggris: John Wiley \& Sons

[5] Biagi, F \& M Falck. (2013). The Impact of ICT and E-Commerce Activities on Employment in Europe. The Ratio Institute: Working Paper No. 285

[6] Borjas, G. J. (2016). Labor Economic Seventh Edition. New York: McGraw Hill

[7] Cardullo, M. W. (1997). Impact of Technology on Employment. Diunduh pada tanggal 28 $8^{\text {th }}$ October 2018 via https://www.researchgate.net/publication/3709726

[8] Duranton, G., Turner, M.A., 2012. Urban growth and transportation. Rev. Econ. Stud. 79(4), 1407-1440
[9] ECLAC (2002). Electronic Commerce, International Trade and Employment: Review of The Issues. UN, Economic comission for Latin America and the Caribbean ECLAC: Washington Office, pp 130

[10] Fraumeni, B. M. (2001). E-commerce: Measurement and measurement issues. The American Economic Review 91(2):318-322

[11] Greene, W. H. (2003). Econometric Analysis Fifth Edition. New Jersey: Pearson

[12] Gujarati, D. N., \& D. C. Porter (2009). Basic Economic $5^{\text {th }}$ Edition. Inggris: Pearson

[13] Ham, and Atkinson, D. R. (2001). A third way framework for global e-commerce. Progressive Policy Institute, Technology \& New Economy Project, pp. 1-29

[14] Julianto, P. A. (2016). Google: Indonesia will capitalized Southeast Asia by Digital Economy. Kompas. Accessed at $10^{\text {th }}$ September 2018 via https://sains.kompas.com/read/2016/08/26/053134926/google.indone sia.akan.kuasai.asia.tenggara.dengan.ekonomi.digital. (in Indonesian)

[15] Kemenperin. (2019). Menperin: Indonesia is ready to lead to digital industry. Kementerian Perindustrian. Accessed at $13^{\text {rd }}$ April 2019 via http://www.kemenperin.go.id/artikel/18846/Menperin:-IndonesiaSiap-Mengarah-ke-Industri-Digital. (in Indonesian)

[16] Manyika, J, et al. (2017). A Future that Works: Automation, Employment, and Productivity. United States: McKinsey Global Institute

[17] Moller, J dan Zierer, M. (2018). Autobahns and Jobs: A Regional Study using Historical Instrumental Variabel. Journal of Urban Economics, Vol 103, pp. $18-33$

[18] Pearson, Mc Leod and S George. (2008). E-Commerce: Business, Technology, and Society. $4^{\text {th }}$ Edition, NewJersey: PrenticeHall, Inc

[19] Pratomo, H. B. (2018). Proft and loss of Industry revolution 4.0 Jokowi version. Merdeka. Accessed at $25^{\text {th }}$ January 2019 via https://www.merdeka.com/uang/untung-rugi-revolusi-industri-40versi-presiden-jokowi.html. (in Indonesian)

[20] Schneider, G. (2012). Electronic Commerce (10 ${ }^{\text {th }}$ edition). Ohio: Cengage Learning

[21] Schwab, K. (2017). The Forth Industrial Revolution. Crown Business Press

[22] Statistics of Indonesia (BPS). (2017). Statistics of Land Transportation 2015 - 2017. Jakarta: Badan Pusat Statistik

[23] Statistics of Indonesia (BPS). (2019). SAKERNAS, 2015-2017. Jakarta: Badan Pusat Statistik

[24] Statistics of Indonesia (BPS). SUSENAS, 2015-2017. Jakarta: Badan Pusat Statistik

[25] Subramani, W. (2001). The impact of e-commerce announcements on the market value of firms. Information Systems Research, 12(2):135154

[26] Suyanto, M. (2003). Advertising Strategies on the World's Top Ecommerce Companies. Yogyakarta: Penerbit Andi. (in Indonesian)

[27] Terzi, N. (2011). Impact of E-Commerce on International Trade and Employment. Marmara University

[28] World Bank. (2017). Internet Users. Download at 27 $7^{\text {th }}$ October 2018 via https://data.worldbank.org/indicator/IT.NET.USER.ZS

[29] World Bank. (2017). Total Population. Download at $27^{\text {th }}$ October 2018 via https://data.worldbank.org/indicator/SP.POP.TOTL

[30] World Trade Organization. (1998). Electronic Commerce. Download at $27^{\text {th }} \quad$ October $2018 \quad$ via https://www.wto.org/english/thewto_e/minist_e/mc11_e/briefing_not es_e/bfecom_e.htm

[31] Yubo, Zhan, dkk. (2012). Collective Agreements, Ownership Systems, and Wage Determination in China's Enterprise: Has Collective Bargaining Improved Wages?. Wages in China: An Economic Analysis, Vol. 03, pp. 54-82 